\title{
FINTECH SERVICES AND FACTORS
}

\section{DETERMINING THE EXPECTED BENEFITS \\ OF USERS: EVIDENCE IN ROMANIA \\ FOR MILLENNIALS AND GENERATION Z}

\section{Octavian Dospinescu', Nicoleta Dospinescu², Daniela-Tatiana Agheorghiesei ${ }^{3}$}

\footnotetext{
1 Alexandru loan Cuza University, Faculty of Economics and Business Administration, Department of Business Information Systems, Romania, ORCID: 0000-0002-5403-8050, doctav@uaic.ro;

2 Alexandru loan Cuza University, Faculty of Economics and Business Administration, Department of Management and Marketing, Romania, ORCID: 0000-0002-7097-7365, dnicole@uaic.ro;

3 Alexandru loan Cuza University, Faculty of Economics and Business Administration, Department of Management and Marketing, Romania, dtc@uaic.ro.
}

\begin{abstract}
The purpose of this research is to define the level of significance for various indicators that influence the degree of consumer satisfaction regarding the use of FinTech technologies and services. The most important factors that influence the level of satisfaction when using FinTech services were considered: comfort and ease of use, legal regulations, ease of account opening, mobile payments features, crowdfunding options, international money transfers features, reduced costs associated with transactions, peer-to-peer lending, insurances options, online brokerage, cryptocoins options and exchange options. The study was conducted on a sample of 162 respondents, persons belonging to the Millennials and Generation Z generations. The values of the indicators for different categories of users of FinTech services and different categories of generations can be determined based on the statistical tests performed and the results obtained from the regression analysis. The values of the indicators are the basic elements for determining the regression model that will help the FinTech service vendors to make personalized decisions for each category of users so that the level of customer satisfaction is maximized. The study carried out within the present article is the first of its kind for Romania, because up to this moment in the specialized literature there are no such studies for Eastern Europe. The research we conducted aims to fill the gap existing in the literature and responds to the expectations and needs of stakeholders in the FinTechs' business area. The results of the article are relevant to both stakeholders and the scientific community that is concerned about the impact of FinTech technologies.
\end{abstract}

Keywords: FinTech, Millennials, Generation Z, FinTech customers satisfaction.

JEL Classification: M31, M37.

APA Style Citation: Dospinescu, O., Dospinescu, N., \& Agheorghiesei, D.-T. (2021). FinTech Services and Factors Determining the Expected Benefits of Users: Evidence in Romania for Millennials and Generation Z. E\&M Economics and Management, 24(2), 101-118. https://doi. org/10.15240/tul/001/2021-2-007

\section{Introduction}

The purpose of this article is to identify the factors that have a decisive influence on the level of satisfaction of users of FinTech services in Romania. To explain the variables that have an effect, we conducted this study both in the entire population of FinTech users, as well as differentiated into two distinct generations: Millennials and Generation Z. From the point of view of age ranges, consumers in the 
Millennials category are also known in the specialty literature (Aichner \& Shaltoni, 2019) as Generation Y, that are people born between the 1980s and the mid-1990s. According to Bucovetchi et al. (2019), Generation Z is the demographic cohort following Millennials and is made up of those born between the second half of the 1990s and early 2000s. These two generations have different behaviors, priorities and preferences when it comes to the use of information technologies.

FinTech is an emerging trend that combines information technology with financial services (Lee \& Jae Shin, 2018), with the main feature being strong innovation in the financial industry. Specialized studies (Ryu, 2018) consider that FinTech does not define a single sector of activity, but covers the entire area of financial products and services that were traditionally offered by banking institutions. Arner et al. (2015) define FinTech as a range of products and services offered by non-banking institutions that use technology disruptively. Of the same opinion are Gomber et al. (2018) who have come to the conclusion that the classic banks are under a real assault from the innovations realized by the newly created companies that generate the concept of "FinTech Revolution", putting in the focus of end consumers and the desire to continuously improve their experiences. Customers are already interacting with financial robots that are capable of satisfying complex demands and making the right decisions depending on the situations in the client's portfolio. According to Zhang and Kedmey (2018), software robots can detect fraudulent behaviors, help establish criteria and values for insurances, make behavioral predictions to help consumers of financial services.

The FinTech effervescence is confirmed by the authors of the literature (Kashyap et al., 2016) who estimate that by 2020 FinTech will reach a market share of $20 \%$ in the financial services industry. Pressed by the competition from FinTechs, banks are heavily investing in digitalisation in an attempt to retain their existing customers.

On the other hand, Ashta and Biot-Paquerot (2018) show that FinTechs are trying to get customers in two ways: 1) by "recruiting" the customers of the classic banks and 2) by accessing the persons who were not in the coverage area of banks (people who are geographically distant from bank branches or persons who for various reasons do not qualify to become a bank customer). These disruptive actions can lead to alliances between classic banks as well as between banks and FinTech challengers in an attempt to preserve their customer base. The adoption rates of FinTechs vary by country; thus, Zigurat (2019) shows that there are countries with very high adoption rates (China - 69\%, India - 52\%, the United Kingdom $-42 \%$, Brazil $-40 \%$ ) and countries with lower adoption rates (Belgium - 13\%, Luxembourg $13 \%$, Japan - 14\%, Canada - 18\%).

Behind these adoption rates of FinTech there are major differences regarding the attitude of generations of consumers. As a result, in this research we focus on highlighting the factors and variables that influence the satisfaction and preferences of users from the 2 technologically representative generations: Millennials and Generation Z.

The article has the following chapters: Introduction, Literature Review, Data and Methodology, Results, Discussion and Conclusions.

\section{Literature Review}

Assarzadeh and Aberoumand (2018) stated that FinTech is a phrase that refers to the combination of financial services and internetbased technologies, being an excellent example of innovation and industrial integration. Specialized studies (e.g. Wonglimpiyarat, 2017) show that at present, the banking landscape is constantly changing under the influence of information technologies. In this context, both banks and non-bank competitors are adopting FinTech with the very clear purpose of being closer to customers. This approach falls within the theoretical framework developed by Davis (1989), that is, in the TAM (technology acceptance model) model according to which the main factors that influence the decision to adopt the new technologies are: 1) perceived ease of use and 2) perceived usefulness.

Ryu (2018) demonstrated that end consumers' intention to use FinTech depends on two categories of factors: 1) perceived benefit and 2) perceived risk. Factors such as economic benefit, convenience and seamless transaction are included in the perceived benefit category. The perceived risks fall into four categories: financial risk, legal risk, security risk and operational risk. In this approach Hu et 
al. (2019) show that the demand of the users for the services offered by the FinTech companies depends very much on the popularity of the internet and the availability of smart mobile devices. Also, government support can influence the degree of acceptance of FinTech services by end consumers, while perceived risk has a negative impact on trust in adoption and use. In terms of ease of use, research shows that it has no significant influence on the decision to adopt FinTech services. In the same line of ideas, Dospinescu et al. (2019) show that the decision to adopt banking products and services differs according to the age generation of which the final consumers belong.

From an architectural point of view, Lee and Jae Shin (2018) consider that the FinTech ecosystem is made up of five major components: (1) FinTech startups, (2) technology developers, (3) government, (4) financial customers and (5) traditional financial institutions. These components contribute symbiotically to the innovative process, stimulate the economy, encourage competition and generate the need for collaboration in the financial industry. Within this complex ecosystem, FinTech startups have a central place because they are the most entrepreneurial component, generating innovations that continuously improve the financial industry. Schulte and Liu (2018) believe that traditional banks are not yet fully prepared for the challenges generated by new information technologies in the context in which decisions will increasingly be made by intelligent machines in areas such as credit risk analysis, data management and insurance.

Since the 2000s, the financial-banking system has diversified strongly and clear functionalities have been introduced under the FinTech trend (Wonglimpiyarat, 2017; Kim et al., 2016): internet card, online banking, digital payments systems, digital money (such as PayPal, Google Wallet, Apple Pay, AliPay, LINE Pay, WePay, M-PESA Mobile money), peerto-peer payments via mobile banking. Many of these new features have been promoted especially by non-banking companies, in an attempt to differentiate themselves from the traditional banks. The FinTech trend causes certain systemic characteristics to change over time and under the influence of market size; as the market grows through collaboration between FinTech partners, the characteristics of the innovation process change substantially. According to Lee and Jae Shin (2018), FinTechs are going through a favorable era in terms of legal regulations as many governments are trying to support their development so that the national financial industries do not lag behind the global ones. It is expected, however, that if FinTechs affect traditional financial markets, governments will impose more stringent rules.

Jagtiani and John (2018) show that authorities around the world are focusing on consumer interest and striving to protect them, trying to strike a balance between financial stability and the need to support creation of an environment conducive to FinTech innovations. From the perspective of the security and confidentiality of transactions, many consumers are concerned about the legal regulations subject to the activities of the FinTechs. Research conducted by Buchak et al. (2018) shows that FinTechs fall into the shadow-banking category due to the fact that they take over the tasks related to lending activities; for mortgage lending, the quantitative model highlighted that regulation represents about $60 \%$ of shadow-banks growth, and the technological component contributes about $30 \%$. Worldwide, the statistics on investments in FinTechs show impressive amounts at the

Tab. 1: Investments in FinTechs (2018)

\begin{tabular}{l|c|c}
\multicolumn{1}{c|}{ Region } & Amount of investments (\$ billion) & Number of deals \\
\hline Global & 111.8 & 2,196 \\
\hline Americas & 54.5 & 1,245 \\
\hline US & 52.5 & 1,061 \\
\hline Europe & 34.2 & 536 \\
\hline Asia & 22.7 & 372 \\
\hline
\end{tabular}

Source: own, data processed from KPMG (2019) 
level of 2018, according to official reports (KPMG, 2019), according to the data in Tab. 1.

From the data in Tab. 1 we can see that the amount invested globally is considerable (more than $\$ 111$ billion), and the United States has a share of about $50 \%$ in this investment sector. Also, it can be noted that globally there are approximately 2,200 FinTech deals, which leads us to think about a very wide diversity of innovative financial initiatives. The same report (KPMG, 2019) shows that in the last 6 years, each region has had an upward trend in terms of the values of the investments made.

According to Ernst \& Young (2019), one of the main disruptive aspects of FinTechs is the first contact with the customer; the ease with which new customers can open a financial account encourages more and more users to adopt this type of technology. At the present time it has come to the situation where the activity of opening a new operational account has a duration of the order of minutes, and the validation of the users is done through artificial intelligence technologies, which leads to an increase in productivity and a significant reduction of the costs of enrolling new clients.

Regarding how FinTech technologies are implemented, a study has been carried out by Du (2018), which has resulted in the fact that in the context of the proliferation of mobile payments, these technologies are of interest not only for the big banks, but also for the credit unions. Thus, credit institutions that have higher-level IT capabilities but are facing lower performance and strong institutional pressures are more likely to adopt mobile payments services. Among the advantages offered in the case of mobile payments, Kang (2018) shows that, unlike the existing bank payment services, the payment service offered by FinTech allows customers using a traditional bank to use an independent and personalized payment service which does not depend on the bank system.

An obvious innovation of FinTechs is being discussed by Magnuson (2018), who shows that these companies have taken to another level how to distribute capital on the market, through crowdfunding platforms. According to Cumming and Hornuf (2018), the concept of crowdfunding refers to the phenomenon where companies in early stages of development (usually startups) seek to obtain financing from large groups of people through Internetbased technologies (most often through social networks or viral marketing campaigns). Abu Amuna et al. (2019) show that the role of FinTechs and crowdfunding platforms is an important one in supporting and accelerating the development of new businesses. Best et al. (2013) estimate that the crowdfunding industry will reach $\$ 96$ billion by 2025 .

Gimpel et al. (2018) show that international money transfers are a successful component of FinTech startups, because they allow much cheaper multi-currency transfers (see Dietz et al., 2016) than through SWIFT or SEPA banking systems. Also, these international transfers made through FinTechs are much faster. Issues related to trading costs are also addressed by Coetzee (2018), who shows that customers are very sensitive to this aspect, being willing to easily migrate from a more expensive traditional financial services provider to an alternative FinTech provider who offers services at lower costs. Cost reduction is a direct result of the fact that FinTechs do not operate through subsidiaries and physical offices as traditional banks do. On the other hand, Ozili (2018) conducted a scientific research which showed that in the case of developed or developing economies, people with variable or low incomes are willing to pay a higher cost for the services offered by FinTech providers; this option is due to the convenience and ease of use in terms of FinTech services.

Gomber et al. (2018) show that a feature that is really interesting to many FinTech users is peer-to-peer (P2P) lending, which conventional banks are not willing to offer. This type of loan refers to the possibility of making direct loans between the lender and the debtor, the FinTech system being an intermediary dealing with issues such as: identifying the borrowers, identifying the creditors, negotiating the direct loan agreement, highlighting the payments for debit and interest, the insurance loan contract, recovery of outstanding amounts. Lee and Jae Shin (2018) and Williams-Grut (2016) note that an important aspect of this business model is the fact that FinTechs are not directly involved in lending (as with traditional banks), but only in "connecting" the creditor with the debtor. FinTechs now tend to integrate in one way or another with established microfinance platforms, platforms that have been analyzed by Bollinger and Yao (2018). According to Jagtiani and Lemieux (2018), options regarding P2P loans were particularly successful in areas 
that were weaker served by traditional banks, which means that a new category of clients has been included in the financial services sphere. In this way, FinTechs manifest themselves as a factor of financial inclusion for various categories of population, which usually would not have access to specific banking services.

In tandem with the P2P lending option, Dietz et al. (2016) show that some FinTechs also offer the possibility to make savings similar to bank deposits. Along the same lines, the provision of online brokerage services by FinTechs to their clients is also closer, thus bringing the stock exchange of small investors closer. FinTechs have gained an increasingly significant market share even among traditional clients of traditional banks. As for Bitcoin cryptocoins, it seems that the level of acceptance by end users is still quite low and somewhat below the level of media impact it has had over the last 3 years. According to Wonglimpiyarat (2017), among the factors that inhibit the widespread adoption of this electronic currency are the fact that it is neither recognized nor supported by any governmental authority, and legal regulations lack or prohibit the use of this means of payment. Given the research elements so far in the literature, a summary of FinTechs' features is presented in Tab. 2 .

\section{Tab. 2: FinTech feature}

\begin{tabular}{|c|c|c|}
\hline FinTech feature & Description & Authors \\
\hline Digital money & $\begin{array}{l}\text { PayPal, Google Wallet, Apple } \\
\text { Pay, AliPay, LINE Pay, WePay, } \\
\text { M-PESA Mobile money }\end{array}$ & $\begin{array}{l}\text { Wonglimpiyarat, 2017; Lee \& Jae } \\
\text { Shin, 2018; Du, 2018; Kang, } 2018\end{array}$ \\
\hline Online-brokerage & $\begin{array}{l}\text { Management of stock-exchange } \\
\text { assets }\end{array}$ & $\begin{array}{l}\text { Gomber et al., 2018; Kashyap } \\
\text { et al., } 2016\end{array}$ \\
\hline Financial robots & $\begin{array}{l}\text { Automatic messages and } \\
\text { answers, intelligent financial } \\
\text { decisions, fraud detection }\end{array}$ & $\begin{array}{l}\text { Zhang \& Kedmey, 2018; Gomber } \\
\text { et al., } 2018\end{array}$ \\
\hline $\begin{array}{l}\text { Peer-to-peer payments via } \\
\text { mobile banking }\end{array}$ & Instant money transfers & $\begin{array}{l}\text { Wonglimpiyarat, 2017; Kim et al., } \\
2016\end{array}$ \\
\hline Peer-to-peer (P2P) lending & Customized lends & $\begin{array}{l}\text { Gomber et al., 2018; Magnuson, } \\
2018\end{array}$ \\
\hline Crypto-currencies & $\begin{array}{l}\text { Bitcoin and assimilated } \\
\text { crypto-coins }\end{array}$ & $\begin{array}{l}\text { Wonglimpiyarat, 2017; Irwin \& } \\
\text { Turner, 2018; Teckla, } 2019\end{array}$ \\
\hline $\begin{array}{l}\text { Online international money } \\
\text { transfer }\end{array}$ & $\begin{array}{l}\text { Transfers within FinTech users or } \\
\text { between FinTech users and banks }\end{array}$ & $\begin{array}{l}\text { Gimpel et al., 2018; Kashyap } \\
\text { et al., } 2016\end{array}$ \\
\hline Savings & Deposits & $\begin{array}{l}\text { Gulamhuseinwala et al., 2015; } \\
\text { Dietz et al., } 2016\end{array}$ \\
\hline Ease of setting up an account & Account opening & Ernst \& Young, 2019 \\
\hline Insurance & $\begin{array}{l}\text { Travel insurance, cards insurance, } \\
\text { lost-documents insurance, loan } \\
\text { insurance }\end{array}$ & $\begin{array}{l}\text { Dany et al., 2016; Gomber et al., } \\
2018\end{array}$ \\
\hline Reduced costs & $\begin{array}{l}\text { Significant reduced cost per } \\
\text { transaction }\end{array}$ & $\begin{array}{l}\text { Dietz et al., 2016; Coetzee, 2018; } \\
\text { Ernst \& Young, } 2019\end{array}$ \\
\hline Exchange & Multi-currency exchanges & $\begin{array}{l}\text { Omarova, 2019; Haddad \& } \\
\text { Hornuf, } 2019\end{array}$ \\
\hline Security \& privacy & $\begin{array}{l}\text { Safe transactions, history of } \\
\text { transactions }\end{array}$ & $\begin{array}{l}\text { Gai et al., 2018; Lee \& Jae Shin, } \\
2018\end{array}$ \\
\hline Crowdfunding & Donations, rewards & $\begin{array}{l}\text { Felländer et al., 2018; Magnuson, } \\
\text { 2018; Best et al., 2013 }\end{array}$ \\
\hline
\end{tabular}


Among the challenges that FinTechs face, Lee and Jae Shin (2018) identify the following main issues: investment management, customer management, regulation, technology integration, security and privacy, and risk management. Zalan and Toufaily (2017) show that another challenge is due to the fact that traditional banks and FinTechs have been forced to work together, which will lead to a diminishing disruptive effect that the FinTech innovations have on them at this moment. As a result, a major challenge will be for FinTechs to be able to maintain the accelerated pace of innovation in the context of collaboration with

\section{Tab. 3: Research hypotheses - indicators}

\begin{tabular}{|c|c|c|}
\hline $\begin{array}{l}\text { Hypothesis } \\
\text { number }\end{array}$ & Hypothesis description & Previous research \\
\hline$H_{1 a}$ & $\begin{array}{l}\text { Comfort and ease of use have a positive impact on the } \\
\text { fulfillment of the benefits expected by the customers from } \\
\text { the use of FinTech services. }\end{array}$ & $\begin{array}{l}\text { Dospinescu et al., 2019; } \\
\text { Davis, 1989; Ernst \& Young, } \\
2019\end{array}$ \\
\hline$H_{1 b}$ & $\begin{array}{l}\text { The existence of legal regulations on FinTechs have } \\
\text { a positive impact on the fulfillment of the benefits } \\
\text { expected by the customers from the use of FinTech } \\
\text { services. }\end{array}$ & $\begin{array}{l}\text { Lee \& Jae Shin, 2018; } \\
\text { Jagtiani \& John, 2018; Van } \\
\text { Loo, 2018; Buchak et al., } \\
2018\end{array}$ \\
\hline$H_{1 c}$ & $\begin{array}{l}\text { The ease with which a new financial account is opened } \\
\text { has a positive impact on the fulfillment of the benefits } \\
\text { expected by the customers from the use of FinTech } \\
\text { services. }\end{array}$ & Ernst \& Young, 2019 \\
\hline$H_{1 d}$ & $\begin{array}{l}\text { The existence of mobile payments options has a positive } \\
\text { impact on the fulfillment of the benefits expected by the } \\
\text { customers from the use of FinTech services. }\end{array}$ & $\begin{array}{l}\text { Du, 2018; Kang, 2018; } \\
\text { Wonglimpiyarat, } 2017\end{array}$ \\
\hline$H_{1 e}$ & $\begin{array}{l}\text { The existence of crowdfunding options have a positive } \\
\text { impact on the fulfillment of the benefits expected by the } \\
\text { customers from the use of FinTech services. }\end{array}$ & $\begin{array}{l}\text { Felländer et al., 2018; } \\
\text { Magnuson, 2018; Best et al., } \\
2013\end{array}$ \\
\hline$H_{1 f}$ & $\begin{array}{l}\text { The international money transfers option has a positive } \\
\text { impact on the fulfillment of the benefits expected by the } \\
\text { customers from the use of FinTech services. }\end{array}$ & $\begin{array}{l}\text { Dietz et al., 2016; Gimpel } \\
\text { et al., 2018; Kashyap et al., } \\
2016\end{array}$ \\
\hline$H_{1 g}$ & $\begin{array}{l}\text { The reduced operation costs have a positive impact on } \\
\text { the fulfillment of the benefits expected by the customers } \\
\text { from the use of FinTech services. }\end{array}$ & $\begin{array}{l}\text { Ozili, 2018; Ernst \& Young, } \\
\text { 2019; Coetzee, } 2018\end{array}$ \\
\hline$H_{1 h}$ & $\begin{array}{l}\text { The existence of peer-to-peer, (P2P) lending options } \\
\text { has a positive impact on the fulfillment of the benefits } \\
\text { expected by the customers from the use of FinTech } \\
\text { services. }\end{array}$ & $\begin{array}{l}\text { Gomber et al., 2018; } \\
\text { Magnuson, } 2018\end{array}$ \\
\hline$H_{1 i}$ & $\begin{array}{l}\text { The insurances included in the system have a positive } \\
\text { impact on the fulfillment of the benefits expected by the } \\
\text { customers from the use of FinTech services. }\end{array}$ & $\begin{array}{l}\text { Dany et al., 2016; Gomber } \\
\text { et al., } 2018\end{array}$ \\
\hline$H_{1 j}$ & $\begin{array}{l}\text { The online-brokerage options have a positive impact on } \\
\text { the fulfillment of the benefits expected by the customers } \\
\text { from the use of FinTech services. }\end{array}$ & $\begin{array}{l}\text { Gomber et al., 2018; } \\
\text { Kashyap et al., } 2016\end{array}$ \\
\hline$H_{1 \mathrm{k}}$ & $\begin{array}{l}\text { The existence of cryptocoins option has a positive } \\
\text { impact on the fulfillment of the benefits expected by the } \\
\text { customers from the use of FinTech services. }\end{array}$ & $\begin{array}{l}\text { Wonglimpiyarat, 2017; Irwin } \\
\text { \& Turner, 2018; Teckla, } 2019\end{array}$ \\
\hline$H_{11}$ & $\begin{array}{l}\text { The exchange option has a positive impact on the } \\
\text { fulfillment of the benefits expected by the customers from } \\
\text { the use of FinTech services. }\end{array}$ & $\begin{array}{l}\text { Omarova, 2019; Haddad \& } \\
\text { Hornuf, } 2019\end{array}$ \\
\hline
\end{tabular}


banks. Ozili (2018) considers that a future direction in researching the challenges related to FinTechs is the study of the relationship between economic crises and digital finance, in the light of how digital finance can contribute or improve the financial contagion in the event of a crisis.

\section{Data and Methodology \\ 2.1 Aim and Hypotheses}

The purpose of this scientific research is to define the influence and contribution of the following 12 indicators: 1) comfort and ease of use, 2) the existence of legal regulations on FinTechs, 3 ) the ease with which a new financial account is opened, 4) mobile payments, 5) existence of crowdfunding options, 6) international money transfers, 7) operating costs, 8) peer-to-peer (P2P) lending, 9) insurances included in the system, 10) online-brokerage, 11) cryptocoins, 12) exchange.

The initial hypothesis is that the aforementioned factors have a significant influence on the decision to adopt FinTech services by customers in Romania. In addition, in this research we will test the dependence of these indicators on the socio-demographic variables, such as: education level, age, monthly income level, gender, user origin (rural vs. urban).

As we presented in the literature review chapter, most previous studies have analyzed these factors individually or in small groups of individual factors. The major contribution of our research lies in the fact that we are trying to provide a broader picture of the number of factors that influence the decision to adopt FinTech services and technologies. Each of the 12 selected indicators will be evaluated by a separate hypothesis, according to Tab. 3 .

In addition to the above, the characteristics related to the level of financial education, the degree of banking development, the purchasing power as well as the demographic characteristics, may cause different decisions from the customers depending on the segments of which they are part. Taking into account the differences between the observed characteristics, the research will focus on identifying the differences between consumers that are different in terms of socio-demographic variables: education level, age, monthly income level, gender, customer's origin (rural vs. urban). As a result, we propose the following set of research hypotheses, according to Tab. 4.

\subsection{Measurement Variables and Instrument}

The research is based on a set of variables that allow the confirmation or rejection of the research hypotheses. The independent variables are the following indicators: comfort and ease of use, the existence of legal regulations on FinTechs, the ease with which a new financial account is opened, mobile payments, existence of crowdfunding options, international money transfers, operating costs, peer-to-peer (P2P) lending, insurances included in the system, online-brokerage, cryptocoins, exchange. The grouping variables are: education level, age,

\section{Tab. 4: Research hypotheses - demographic factors}

\begin{tabular}{c|l}
$\begin{array}{c}\text { Hypothesis } \\
\text { number }\end{array}$ & \multicolumn{1}{c}{ Hypothesis description } \\
\hline$H_{2 a}$ & $\begin{array}{l}\text { Benefits expected by customers through the use of FinTech services differ according } \\
\text { to age. }\end{array}$ \\
\hline$H_{2 b}$ & $\begin{array}{l}\text { Benefits expected by customers through the use of FinTech services differ according } \\
\text { to education level. }\end{array}$ \\
\hline$H_{2 c}$ & $\begin{array}{l}\text { Benefits expected by customers through the use of FinTech services differ according } \\
\text { to income level. }\end{array}$ \\
\hline$H_{2 d}$ & $\begin{array}{l}\text { Benefits expected by customers through the use of FinTech services differ according } \\
\text { to gender. }\end{array}$ \\
\hline$H_{2 e}$ & $\begin{array}{l}\text { Benefits expected by customers through the use of FinTech services differ according } \\
\text { to customer's origin (rural vs. urban). }\end{array}$ \\
\hline
\end{tabular}


monthly income level, gender, customer's origin (rural vs. urban).

The decision to adopt FinTech services was analyzed through a questionnaire containing 17 questions: 5 questions refer to the demographic characteristics of the group and 12 questions refer to the independent variables. Respondents were asked to assess to what extent each indicator is important in the expected benefits of using FinTech services and technologies; the questions were constructed on the Likert scale, where the value 1 means that the measured variable has no importance in the decision to adopt FinTechs, while the value 5 means that the variable has an increased importance in this decision. The questions allowed respondents to choose a value from 1 to 5 for each response associated with the variable: 1) How important are the comfort and ease of use in the decision to adopt FinTech? 2) How important is the existence of legal regulations on FinTechs to you in the decision to adopt FinTech? 3) How important is the ease with which a new financial account is opened in the decision to adopt FinTech? 4) How important is the mobile payments option in the decision to adopt FinTech? 5) How important is the option regarding international money transfers in the decision to adopt FinTech services?

To verify the reliability of the questionnaire, we applied the Cronbach's Alpha test. The test verifies the internal consistency from the point of view of the individual scores and the aggregate score. The values of Cronbach's Alpha test is 0.610 and according to Tavakol and Dennick (2011), this value confirms that our items are acceptable.

\subsection{Research Population, Sampling Method and Sample}

The research population is represented by users of FinTech technologies and services, who are members of Millennials and Generation Z. The sampling method used was the Purposive Sampling. The researchers considered the specific characteristics, qualities, knowledge and experience of the respondents the relevant criteria for the research (Etikan et al., 2016).

This research was based on the responses of 162 respondents. The number of respondents is higher than the minimum number (139) suggested by Raosoft (2019) for a confidence level of $95 \%$. The distribution of respondents shows a normal distribution, reflecting the properties of the entire population in the analyzed segment. In terms of gender, the sample consists of $45.7 \%$ male respondents and $54.3 \%$ female respondents. From the point of view of the income level, $8.6 \%$ of the respondents have below average incomes, $69.2 \%$ have average incomes and $22.2 \%$ have above average incomes. From the point of view of the origin (rural vs. urban), $77.8 \%$ of the respondents come from the urban environment and $22.2 \%$ from the rural area. Most respondents have a university degree $(63.6 \%)$, and $31.5 \%$ of them have completed their masters studies, while $1.2 \%$ have high school and $3.7 \%$ doctoral studies. In terms of age, $48.8 \%$ are from the Generation Z category, while $51.2 \%$ are from the Millennials category.

\subsection{Procedure and Statistical Analysis of Data}

The questionnaire was applied in July, August and September 2019 in Romania. The data collected from the respondents were processed with IBM SPSS Statistics version 21. The answers obtained from the respondents were analyzed by the descriptive statistics method, being presented average values as well as deviation for each variable. The accuracy of the set of hypotheses is analyzed using various statistical tests: Pearson correlation, multivariate analysis of variance and multiple regression analysis and modeling.

\section{Results}

The values of the descriptive statistics for the dependent variable (the satisfaction level regarding the use of FinTech services) and the specific indicators are presented in Tab. 5. As it can be seen, the respondents consider that the level of satisfaction with the use of FinTech services depends largely on reduced costs $(M=4.59)$, mobile payments $(M=4.53)$, attached insurances $(M=4.43)$, ease of opening a new financial account $(M=4.15)$ and international money transfer options $(M=4.23)$. In the same context, low satisfaction is associated with crowdfunding options ( $M=1.53)$, cryptocoins options $(M=1.56)$, online brokerage $(M=1.81)$, and peer-to-peer lending options $(M=2.40)$.

These values obtained from our research confirm some previous partial research on reduced costs (Coetzee, 2018; Dietz et al., 2016), attached insurances (Dany et al., 2016; Gomber et al., 2018) and international money 


\section{Tab. 5: Values of descriptive statistics for dependent variable and indicators}

\begin{tabular}{l|c|c|c|c}
\multicolumn{1}{c|}{ Indicators } & Minimum & Maximum & Mean & Std. deviation \\
\hline ComfortAndEaseOfUse & 1.00 & 5.00 & 3.7963 & 1.0224 \\
\hline LegalRegulations & 1.75 & 5.00 & 3.8426 & 0.7032 \\
\hline EaseAccountOpen & 1.75 & 5.00 & 4.1543 & 0.6219 \\
\hline MobilePayments & 2.00 & 5.00 & 4.5309 & 0.6419 \\
\hline Crowdfunding & 1.00 & 5.00 & 1.5340 & 0.8522 \\
\hline InternationalMoneyTransfers & 1.00 & 5.00 & 4.2346 & 0.7765 \\
\hline ReducedCosts & 2.75 & 5.00 & 4.5941 & 0.6716 \\
\hline P2PLending & 1.00 & 5.00 & 2.4074 & 1.2538 \\
\hline Insurances & 2.00 & 5.00 & 4.4321 & 0.5963 \\
\hline OnlineBrokerage & 1.00 & 5.00 & 1.8148 & 1.0469 \\
\hline CryptocoinsOption & 1.00 & 5.00 & 1.5617 & 0.9119 \\
\hline ExchangeOption & 1.00 & 5.00 & 4.1790 & 0.8626 \\
\hline SatisfactionLevelFinTech & 3.00 & 5.00 & 4.2654 & 0.6185 \\
\hline
\end{tabular}

\section{Tab. 6: Contribution of independent variables to dependent variable description}

\begin{tabular}{l|c|c|c}
\multirow{2}{*}{ Model } & Standardized coefficients & \multirow{2}{*}{ T } & Sig. \\
\cline { 2 - 3 } & $-0.107^{*}$ & -2.024 & 0.045 \\
\hline ComfortAndEaseOfUse & $0.141^{*}$ & 2.163 & 0.032 \\
\hline LegalRegulations & -0.013 & -0.241 & 0.810 \\
\hline EaseAccountOpen & $0.136^{*}$ & 2.117 & 0.036 \\
\hline MobilePayments & 0.055 & 1.077 & 0.283 \\
\hline Crowdfunding & $0.128^{*}$ & 2.370 & 0.019 \\
\hline InternationalMoneyTransfers & $0.460^{* *}$ & 8.003 & 0.000 \\
\hline ReducedCosts & 0.052 & 0.973 & 0.332 \\
\hline P2PLending & $0.177^{* *}$ & 3.179 & 0.002 \\
\hline Insurances & 0.080 & 1.514 & 0.132 \\
\hline OnlineBrokerage & 0.009 & 0.171 & 0.865 \\
\hline CryptocoinsOption & $0.106^{*}$ & 2.059 & 0.041 \\
\hline ExchangeOption & & & 504 \\
\hline
\end{tabular}

Note: ${ }^{*}$ significant at the level $5 \%$; ${ }^{* *}$ significant at the level $1 \%$.

transfer options (Gimpel et al., 2018; Kashyap et al., 2016).

To test hypotheses $H_{1 a}-H_{11}$, multiple linear regression analysis was used to try to predict the dependent variable (satisfaction level in using FinTech services) based on a set of independent variables: comfort and ease of use, legal regulations, ease of 
account opening, mobile payments features, crowdfunding options, international money transfers options, reduced costs associated with financial transactions, peer-to-peer lending options, insurances options, online brokerage, cryptocoins features, exchange options. Our multiple linear regression analysis is based on the Enter method, which includes all variables in the model and thus all variables start with the same initial value. The individual contributions of each indicator are presented in detail in Tab. 6, where the Beta column refers to the standardized values.

Based on the regression analysis and the results obtained, we can conclude that this set of indicators statistically significantly predicts the dependent variable $(F=24.788 ; p<0.01)$. It is also important to note that Adjusted R-squared is 0.639 , showing a strong correlation between the analyzed variables.

To be sure that our model is relevant, we performed the multicollinearity test of the independent variables using VIF (variance inflation factor) and obtained the data from Tab. 7.

According to Hair et al. (2014), considering that all VIF values are lower than 2.00 , it is obvious that in our model there is no problem of multicollinearity. These values obtained from the VIF test certify that our regression model is valid.
Regarding the individual contribution of each indicator, based on the data obtained in Tab. 6 it can be observed that Reduced Costs is acting in a positive direction (Beta $=0.460$ ); this means that FinTech users are most sensitive to the costs associated with the financial transactions carried out through FinTech applications. Also of importance to customers are the Insurances (Beta $=0.177$ ), Legal Regulations (Beta $=0.141)$, Mobile Payments (Beta $=0.136)$, International Money Transfers (Beta $=0.128)$ and Exchange Options (Beta $=0106)$. On the other hand, Comfort and Ease of Use (Beta $=-0.107$ ) has an influence in a negative direction. The variables that according to the respondents do not contribute to the satisfaction of using the FinTech services are Ease of Account Opening, Crowdfunding features, peer-to-peer lending options, online brokerage and cryptocoins options.

Based on the results obtained, we can conclude that hypotheses $H_{1 a}, H_{1 b}, H_{1 d}, H_{1 \text {, }}$, $H_{19}, H_{1 i}$ and $H_{11}$ are confirmed. This means that correlations are confirmed for variables related to comfort and ease of use, legal regulations, mobile payments, international money transfers options, reduced costs associated with transactions, insurances options and exchange options. The assumptions are not confirmed for the variable $H_{1 c}$ ease of account opening,

Tab. 7: Collinearity statistics for the explanatory variables

\begin{tabular}{l|c|c}
\multirow{2}{*}{\multicolumn{1}{c|}{ Explanatory variables }} & \multicolumn{2}{c}{ Collinearity statistics } \\
\cline { 2 - 3 } & Tolerance & VIF \\
\hline ComfortAndEaseOfUse & 0.799 & 1.251 \\
\hline LegalRegulations & 0.526 & 1.903 \\
\hline EaseAccountOpen & 0.790 & 1.267 \\
\hline MobilePayments & 0.539 & 1.855 \\
\hline Crowdfunding & 0.873 & 1.145 \\
\hline InternationalMoneyTransfers & 0.771 & 1.298 \\
\hline ReducedCosts & 0.678 & 1.475 \\
\hline P2PLending & 0.781 & 1.280 \\
\hline Insurances & 0.721 & 1.386 \\
\hline OnlineBrokerage & 0.806 & 1.240 \\
\hline CryptocoinsOption & 0.900 & 1.111 \\
\hline ExchangeOption & 0.844 & 1.185 \\
\hline
\end{tabular}


which means that for the researched sample, the level of satisfaction regarding the use of FinTech services is not statistically significantly influenced by the ease of opening a new financial account. Also, hypotheses $H_{1 e}, H_{1 h}, H_{1 j}$ and $H_{1 k}$ are not supported.

In order to test the second group of hypotheses $\mathrm{H}_{2 a}-\mathrm{H}_{2 e}$ a multivariate analysis of variance was performed to see if the expected benefits in terms of comfort and ease of use, legal regulations, ease of account opening, mobile payments, crowdfunding, international money transfers, reduced costs, P2P lending, insurances, online brokerage, cryptocoins, exchange options differ depending on the socio-demographic variables: age, gender, income level, place of residence (rural/ urban), education level. It was found that the individual contribution is made only by sociodemographic variable $H_{2 a}$-Age (Millennials vs. Generation Z). This means that the satisfaction of the FinTech users is influenced differently by age, that is, the generation of the users. The largest differences between Millennials and Generation $Z$ are registered for the variables: comfort and ease of use $(F=7.982 ; p<0.01)$, legal regulations $(F=14.935 ; p<0.01)$, mobile payments $(F=9.245 ; p<0.01)$, reduced costs $(F=10.631 ; p<0.01)$, insurances $(F=6.054$; $p<0.05)$, cryptocoins options $(F=4.516$; $\mathrm{p}<0.05)$.

In view of the above analysis, as well as the data in Tab. 8, it is very clear that hypothesis $H_{2 a}$ regarding age generations is partially confirmed, whereas hypotheses $H_{2 b}, H_{2 c}, H_{2 d}$ and $H_{2 e}$ are not confirmed.

\section{Tab. 8: Contribution of predictors to the explanation of dependent variables - Part 1}

\begin{tabular}{|c|c|c|c|}
\hline Source & Dependent variable & $\mathbf{F}$ & Sig. \\
\hline \multirow[t]{12}{*}{ Age } & ComfortAndEaseOfUse & $7.982^{* *}$ & 0.006 \\
\hline & LegalRegulations & $14.935^{* *}$ & 0.000 \\
\hline & EaseAccountOpen & 0.502 & 0.480 \\
\hline & MobilePayments & $9.245^{\star *}$ & 0.003 \\
\hline & Crowdfunding & 0.273 & 0.602 \\
\hline & InternationalMoneyTransfers & 1.405 & 0.238 \\
\hline & ReducedCosts & $10.631^{* *}$ & 0.001 \\
\hline & P2PLending & 0.326 & 0.569 \\
\hline & Insurances & $6.054^{*}$ & 0.015 \\
\hline & OnlineBrokerage & 0.469 & 0.495 \\
\hline & CryptocoinsOption & $4.516^{*}$ & 0.036 \\
\hline & ExchangeOption & 1.189 & 0.278 \\
\hline \multirow[t]{12}{*}{ Gender } & ComfortAndEaseOfUse & 0.485 & 0.488 \\
\hline & LegalRegulations & 0.198 & 0.657 \\
\hline & EaseAccountOpen & 0.005 & 0.945 \\
\hline & MobilePayments & 0.005 & 0.944 \\
\hline & Crowdfunding & 0.643 & 0.424 \\
\hline & InternationalMoneyTransfers & 1.794 & 0.183 \\
\hline & ReducedCosts & 0.336 & 0.563 \\
\hline & P2PLending & 0.368 & 0.545 \\
\hline & Insurances & 0.389 & 0.534 \\
\hline & OnlineBrokerage & 0.529 & 0.469 \\
\hline & CryptocoinsOption & 0.160 & 0.690 \\
\hline & ExchangeOption & 0.002 & 0.969 \\
\hline
\end{tabular}




\section{Tab. 8: Contribution of predictors to the explanation of dependent variables - Part 2}

\begin{tabular}{|c|c|c|c|}
\hline Source & Dependent variable & $\mathbf{F}$ & Sig. \\
\hline \multirow[t]{12}{*}{ IncomeLevel } & ComfortAndEaseOfUse & 0.555 & 0.576 \\
\hline & LegalRegulations & 1.925 & 0.150 \\
\hline & EaseAccountOpen & 0.353 & 0.703 \\
\hline & MobilePayments & 2.242 & 0.111 \\
\hline & Crowdfunding & 0.148 & 0.863 \\
\hline & InternationalMoneyTransfers & 2.832 & 0.063 \\
\hline & ReducedCosts & 0.097 & 0.908 \\
\hline & P2PLending & $3.125^{*}$ & 0.048 \\
\hline & Insurances & 0.848 & 0.431 \\
\hline & OnlineBrokerage & 0.156 & 0.855 \\
\hline & CryptocoinsOption & $6.528^{* *}$ & 0.002 \\
\hline & ExchangeOption & 1.818 & 0.167 \\
\hline \multirow[t]{12}{*}{ RuralUrban } & ComfortAndEaseOfUse & 0.118 & 0.732 \\
\hline & LegalRegulations & 0.547 & 0.461 \\
\hline & EaseAccountOpen & 1.304 & 0.256 \\
\hline & MobilePayments & 1.550 & 0.216 \\
\hline & Crowdfunding & 0.115 & 0.736 \\
\hline & InternationalMoneyTransfers & $4.587^{*}$ & 0.034 \\
\hline & ReducedCosts & 0.391 & 0.533 \\
\hline & \begin{tabular}{|l|} 
P2PLending \\
\end{tabular} & 0.169 & 0.682 \\
\hline & Insurances & 0.318 & 0.574 \\
\hline & OnlineBrokerage & 3.871 & 0.051 \\
\hline & CryptocoinsOption & 0.229 & 0.633 \\
\hline & ExchangeOption & 0.016 & 0.900 \\
\hline \multirow[t]{12}{*}{ EducationLevel } & ComfortAndEaseOfUse & 1.456 & 0.230 \\
\hline & LegalRegulations & 1.195 & 0.315 \\
\hline & EaseAccountOpen & 2.300 & 0.081 \\
\hline & MobilePayments & 1.082 & 0.360 \\
\hline & Crowdfunding & 0.265 & 0.851 \\
\hline & InternationalMoneyTransfers & 1.483 & 0.223 \\
\hline & ReducedCosts & 0.465 & 0.707 \\
\hline & \begin{tabular}{|l|} 
P2PLending \\
\end{tabular} & 0.732 & 0.535 \\
\hline & Insurances & 1.431 & 0.237 \\
\hline & OnlineBrokerage & 1.268 & 0.289 \\
\hline & CryptocoinsOption & 1.859 & 0.140 \\
\hline & ExchangeOption & 0.137 & 0.938 \\
\hline
\end{tabular}

Note: ${ }^{*}$ significant at the level $5 \%,{ }^{* *}$ significant at the level $1 \%$. 
Tab. 9: $\quad$ Regression analysis for Millennials vs. Generation Z

\begin{tabular}{l|c|c|c|c}
\multicolumn{1}{c|}{ Model } & \multicolumn{2}{c|}{$\begin{array}{c}\text { Millennials - standardized } \\
\text { coefficients }\end{array}$} & \multicolumn{2}{c}{$\begin{array}{c}\text { Generation Z - standardized } \\
\text { coefficients }\end{array}$} \\
\hline & Beta & Sig. & Beta & Sig. \\
\hline ComfortAndEaseOfUse & 0.068 & 0.305 & 0.066 & 0.551 \\
\hline LegalRegulations & $0.277^{* *}$ & 0.000 & 0.009 & 0.929 \\
\hline EaseAccountOpen & -0.099 & 0.129 & -0.157 & 0.156 \\
\hline MobilePayments & 0.050 & 0.512 & 0.150 & 0.137 \\
\hline Crowdfunding & $0.142^{*}$ & 0.020 & -0.029 & 0.760 \\
\hline InternationalMoneyTransfers & -0.050 & 0.439 & $0.352^{* *}$ & 0.002 \\
\hline ReducedCosts & $0.556^{* *}$ & 0.000 & $0.490^{* *}$ & 0.000 \\
\hline P2PLending & 0.000 & 0.995 & -0.010 & 0.928 \\
\hline Insurances & $0.177^{* *}$ & 0.006 & -0.071 & 0.433 \\
\hline OnlineBrokerage & $0.142^{*}$ & 0.026 & 0.180 & 0.061 \\
\hline CryptocoinsOption & -0.025 & 0.673 & 0.041 & 0.672 \\
\hline ExchangeOption & $0.139^{*}$ & 0.021 & $0.216^{*}$ & 0.032 \\
\hline
\end{tabular}

Source: own

Note: * significant at the level $5 \%$, ${ }^{* *}$ significant at the level $1 \%$.

In the analysis for the group of sociodemographic variables, the tests revealed statistically significant differences only for the variable Age $H_{2 a}$ (Millennials vs. Generation Z). Based on this result, the analysis will focus on the differences between the two groups of respondents and we will use the multiple regression analysis customized for each generation separately. The results of these differentiated analyzes are presented in Tab. 9.

The regression equations obtained are statistically significant for each of the analyzed generations (Millennials: $F=22.694$; $p<0.01$; Generation Z: F $=6.612 ; p<0.01$ ) and it can therefore be concluded that the differences between consumers in the Millennials generation and those in Generation $Z$ statistically significantly affect satisfaction with the use of FinTech services.

The data obtained in Tab. 9 shows that the level of satisfaction of the use of FinTech services by Millennials consumers is positively influenced by the existence of legal regulations (Beta $=0.277)$, crowdfunding options $($ Beta $=0.142)$, reduced costs $($ Beta $=0.556)$, insurances options (Beta $=0.177$ ), online brokerage options (Beta $=0.142$ ) and exchange options $($ Beta $=0.139)$. On the other hand, for Millennials, comfort and ease of use (Beta $=0.068 ; p>0.05)$, ease of account opening (Beta $=-0.099 ; \mathrm{p}>0.05$ ), mobile payments (Beta $=0.050 ; p>0.05), \mathrm{P} 2 \mathrm{P}$ lending (Beta $=0.00 ; p>0.05)$, cryptocoins options (Beta $=-0.025 ; p>0.05)$ have no statistically significant impact. In the case of Generation Z, the satisfaction level of using FinTech services is positively determined by international money transfers options (Beta $=0.352 ; p<0.01$ ), reduced costs (Beta $=0.490 ; p<0.01)$, exchange options (Beta $=0.216 ; p<0.05$ ). The other variables have no statistically significant influence for consumers belonging to Generation Z.

In order to better highlight the level of influence of each indicator in the regression model, the significance levels for the indicators analyzed in the two study groups are represented in Fig. 1.

The analysis performed in the research confirms with certainty that there are statistically significant differences between the users of the FinTech technologies from the Millennials and Generation Z generations in terms of comfort and ease of use, legal regulations, ease of account opening, mobile payments, crowdfunding options, international money 


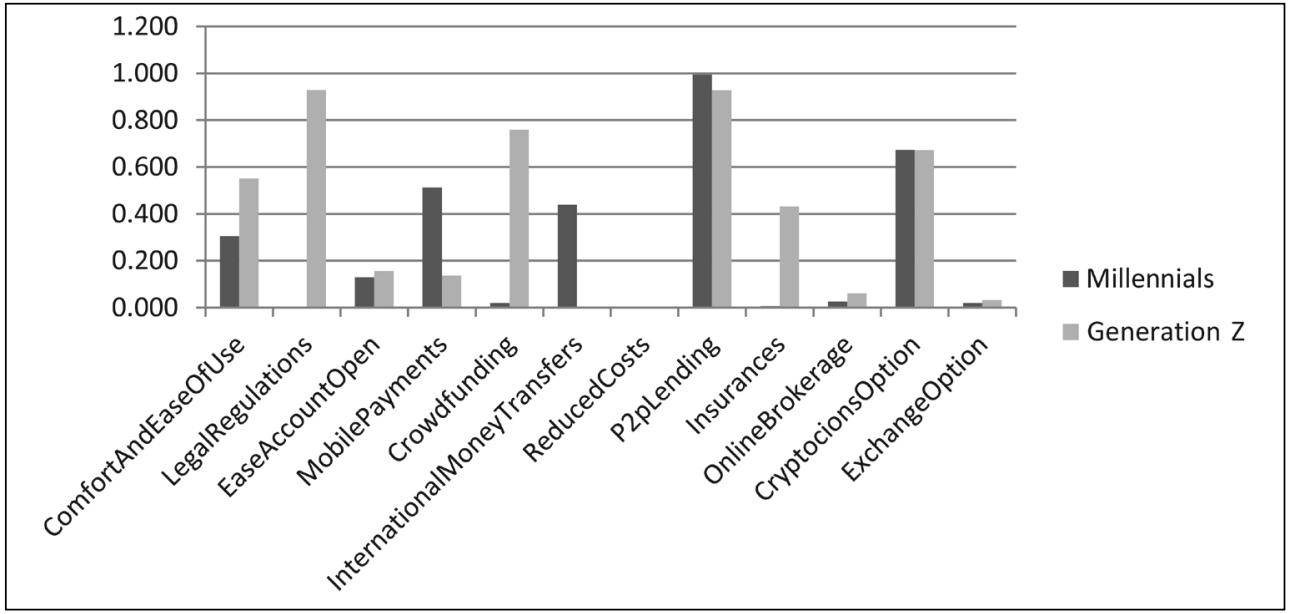

transfers options, reduced costs associated with the transactions, peer-to-peer lending, associated insurances, online brokerage, cryptocoins options and exchange options.

\section{Discussion}

The analyzes and tests carried out revealed that the satisfaction level of FinTech technologies for users in Millennials and Generation Z categories is correlated with comfort and ease of use, legal regulations, mobile payments, international money transfers options, associated reduced costs, insurances options, and exchange options. The multiple regression equation for the entire sample of Millennials and Generation $Z$ customers shows that the level of satisfaction with the use of FinTech technologies can be expressed through the selected indicators. The equation of the linear multiple regression model containing only statistically significant indicators can be represented according to formula (1):

$$
\begin{aligned}
& y=-0.235-0.107 x_{1}+0.141 x_{2}+ \\
& +0.136 x_{3}+0.128 x_{4}+0.460 x_{5}+ \\
& +0.177 x_{6}+0.106 x_{7}
\end{aligned}
$$

In formula (1) $y$ is the dependent variable (the satisfaction level of FinTech customers), while the variables $x$ are independent indicators, as follows: $x_{1}$-comfort and ease of use; $x_{2}$ - legal regulations; $x_{3}$-mobile payments features; $x_{4}$ - international money transfers options; $x_{5}$ - reduced costs; $x_{6}-$ insurances; $x_{7}$ - exchange options.

The formula shows that the satisfaction level of the users of FinTech technologies can be estimated through 7 of the 12 indicators included in the questionnaire. As it can be seen, the values of the variables' coefficients indicate that the customers' satisfaction with the use of FinTech technologies positively depends on legal regulations, mobile payments features, international money transfers options, reduced costs, insurances and exchange options. Based on this result, FinTech companies can focus their efforts on improving their own technologies in order to provide customers with exactly what is important to them. These results confirm the partial results previously obtained by Jagtiani and John (2018), Lee and Jae Shin (2018), Kim et al. (2016), Coetzee (2018) and Gomber et al. (2018).

The multiple regression equations for the two distinct age groups show us that in Romania each group is sensitive to a different set of predictive indicators, according to formula (2) (Millennials) and formula (3) (Generation Z).

$$
\begin{aligned}
& y=0.869+0.277 x_{1}+0.142 x_{2}+ \\
& +0.556 x_{3}+0.177 x_{4}+0.142 x_{5}+ \\
& +0.139 x_{6}
\end{aligned}
$$




$$
\begin{aligned}
& y=0.244+0.352 x_{1}+0.490 x_{2}+ \\
& +0.216 x_{3}
\end{aligned}
$$

In the case of the Millennials generation, we have no less than six variables that are statistically significant: $x_{1}-$ legal regulations, $x_{2}-$ crowdfunding options, $x_{3}$ - reduced costs, $x_{4}$ - insurances options, $x_{5}$ - online brokerage features, $x_{6}-$ exchange options, over time what for the Generation $Z$ generation we have three statistically significant indicators: $x_{1}$ - international money transfer features, $x_{2}$ - reduced costs, $x_{3}$ - exchange options. Regarding the influence of the demographic factors on the analyzed variables, from the analysis of the research hypotheses $\mathrm{H}_{2 a}-\mathrm{H}_{2}$, it is confirmed only the $H_{2 b}$ hypothesis according to which the level of satisfaction of the users of FinTech technologies differs according to age. Hypotheses $H_{2 a}, H_{2 c}, H_{2 d}$ and $H_{2 e}$ are rejected.

\section{Conclusions}

The justification of this research realized within the article is determined by the fact that the world we are aiming for is increasingly technologized and oriented towards the adoption of new information technologies. Thus, FinTech technologies occupy an increasingly important market share and the level of user satisfaction is an interest factor both for the promoters of this industry and for the competition in the classical banking environment. The data shows very clearly that the number of FinTech customers is growing rapidly, as well as the number and volume of transactions made through these technologies. This means that FinTech technology developers need to be very attentive to the specific needs of each consumer category, as well as the incentives they are responding to. It is also relevant to mention that there are no scientific studies to date regarding the behavior of consumers in Eastern Europe and Romania. As a result, our contribution is that the results obtained from the research in our article cover a gap in the literature regarding FinTech technologies in this area of the world.

Research and tests conducted in this study show that the most important factors in terms of statistical significance for the degree of satisfaction in using FinTech services are legal regulations, crowdfunding options, reduced costs, insurances options, online brokerage features, exchange options (for the Millennials), while for Generation Z users are important international money transfer features, reduced costs, exchange options. These aspects in fact reflect the essence of research and practical contribution because they provide solid indications to FinTech service providers about the factors to be considered for various categories of consumers, so that the perception is positively influenced. The research also highlights the fact that clients with different socio-demographic variables (excluding the separation between Millennials and Generation $Z$ generations) are not different in terms of the level of perception of satisfaction offered by the use of FinTech services. These concrete results that have been validated through our research could be included in specialized academic courses such as modern services marketing, business management, FinTech services administration, banking services marketing.

Regarding the limitations of the research, they refer to: (a) Territorial limits of the research, given that the analyzed sample contains only respondents from Romania. An objective motivation of this limitation is that the FinTech services and the related customers differ from one country to another and from one continent to another, (b) 12 variables/factors of influence were analyzed in this research, which could generate a relatively simplified picture of the whole phenomenon.

With regard to future research directions, the current topic can be expanded by conducting a global study by comparing at continents or large regions of the world. Also, a future direction may be a more detailed analysis on various consumer clusters. The inclusion of a wider range of indicators/variables and their cross-testing may further develop the study conducted in this article.

\section{References}

Abu Amuna, Y., Abu-Naser, S. S., Al Shobaki, M. J., \& Abu Mostafa, Y. A. (2019). Fintech: Creative Innovation for Entrepreneurs. International Journal of Academic Accounting, Finance and Management Research, 3(3), 8-15.

Aichner, T., \& Shaltoni, A. M. (2019). Making market research work in Saudi Arabia. International Journal of Market Research, 61(1), 10-11. https://doi.org/10.1177/1470785318754978

Arner, D. W., Barberis, J. N., \& Buckley, R. P. (2015). The Evolution of Fintech: A New 
Post-Crisis Paradigm? SSRN Electronic Journal, 47(4), 1271-1319. https://doi. org/10.2139/ssrn.2676553

Ashta, A., \& Biot-Paquerot, G. (2018). FinTech evolution: Strategic value management issues in a fast changing industry. Stragegic Change. Briefings in Entrepreneurial Finance, 27(4), 301-311. https://doi.org/10.1002/jsc.2203

Assarzadeh, A. H., \& Aberoumand, S. (2018). FinTech in Western Asia: Case of Iran. Journal of Industrial Integration and Management, 3(3). https://doi.org/10.1142/S2424862218500069

Best, J., Neiss, S., Swart, R., Lambkin, A., \& Raymond, S. (2013). Crowdfunding's potential for the developing world (Working Paper No. 84000). Washington, DC: World Bank Group. Retrieved from http://documents. worldbank.org/curated/en/409841468327411701/ Crowdfundings-potential-for-the-developing-world

Bollinger, B., \& Yao, S. (2018). Risk transfer versus cost reduction on two-sided microfinance platforms. Quantitative Marketing and Economics, 16(3), 251-287. https://doi. org/10.1007/s11129-018-9198-0

Buchak, G., Matvos, G., Piskorski, T., \& Seru, A. (2018). Fintech, regulatory arbitrage, and the rise of shadow banks. Journal of Financial Economics, 130(3), 453-483. https://doi.org/10.1016/j.jfineco.2018.03.011

Bucovetchi, O., Slusariuc, G., \& Činčalová, S. (2019). Generation Z - Key factor for organizational innovation. Quality - Access to Success, 20(3), 25-30.

Coetzee, J. (2018). Strategic implications of Fintech on South African retail banks. South African Journal of Economic and Management Sciences, 21(1), 1-11. http://dx.doi.org/10.4102/sajems.v21i1.2455

Cumming, D., \& Hornuf, L. (2018). The Economics of Crowdfunding. Startups, Portals and Investor Behavior. London: Palgrave Macmillan. https://doi.org/10.1007/978-3-319-66119-3

Dany, O., Goyal, R., Schwarz, J., Van den Berg, P., Scortecci, A., \& to Baben, S. (2016). Fintechs may be corporate banks' best "Frenemies". Boston, MA: Boston Consulting Group. Retrieved July 24, 2019, from https:// www.bcg.com/publications/2016/financialinstitutions-technology-digital-FinTechs-maybe-corporate-banks-best-frenemies.aspx

Davis, F. (1989). Perceived usefulness, perceived ease of use, and user acceptance of information technology. MIS Quarterly, 13(3), 319-340. https://doi.org/10.2307/249008
Dietz, M., Olanrewaju, T., Khanna, S., \& Rajgopal, K. (2016). Cutting through the noise around financial technology. New York, NY: McKinsey \& Company. Retrieved from https://www.mckinsey.com/industries/financialservices/our-insights/cutting-through-the-noisearound-financial-technology

Dospinescu, O., Anastasiei, B., \& Dospinescu, N. (2019). Key Factors Determining the Expected Benefit of Customers When Using Bank Cards: An Analysis on Millennials and Generation Z in Romania. Symmetry, 11(12), 1449. https://doi.org/10.3390/sym11121449

Du, K. (2018). Complacency, capabilities, and institutional pressure: understanding financial institutions' participation in the nascent mobile payments ecosystem. Electronic Markets, 28(3), 307-319. https://doi. org/10.1007/s12525-017-0267-0

Ernst \& Young. (2019). Global FinTech Adoption Index 2019. London: Ernst \& Young. Retrieved from https://assets.ey.com/ content/dam/ey-sites/ey-com/en_gl/topics/ banking-and-capital-markets/ey-global-fintechadoption-index.pdf

Etikan, I., Musa, S. A., \& Alkassim, R. S. (2016). Comparison of Convenience Sampling and Purposive Sampling. American Journal of Theoretical and Applied Statistics, 5(1), 1-4. https://doi.org/10.11648/j.ajtas.20160501.11

Felländer, A., Siri, S., \& Teigland, R. (2018). The three phases of FinTech. In R. Teigland, S. Siri, A. Larsson, A. Moreno Puertas, \& C. Ingram Bogusz (Eds.), The Rise and Development of FinTech. Accounts of Disruption from Sweden and Beyond (pp. 154-167). London: Routledge.

Gai, K., Qiu, M., \& Sun, X. (2018). A survey on FinTech. Journal of Network and Computer Applications, 103, 262-273. https://doi. org/10.1016/j.jnca.2017.10.011

Gimpel, H., Rau, D., \& Röglinger, M. (2018). Understanding FinTech start-ups - a taxonomy of consumer-oriented service offerings. Electronic Markets, 28(3), 245-264. https://doi. org/10.1007/s12525-017-0275-0

Gomber, P., Kauffman, R. J., Parker, C., \& Weber, B. W. (2018). On the Fintech revolution: Interpreting the forces of innovation, disruption and transformation in financial services. Journal of Management Information Systems, 35(1), 220-265. https://doi.org/10.1080/07421222.20 18.1440766

Gulamhuseinwala, I., Bull, T., \& Lewis, S. (2015). FinTech is gaining traction and young, 
high-income users are the early adopters. The Journal of Financial Perspectives, 3(3), 1-17.

Haddad, C., \& Hornuf, L. (2019). The emergence of the global FinTech market: economic and technological determinants. Small Business Economics, 53(1), 81-105. https://doi.org/10.1007/s11187-018-9991-x

Hair, J. F., Black, W. C., Babin, B. J., \& Anderson, R. E. (2013). Multivariate Data Analysis. London: Pearson.

Hu, Z., Ding, S., Li, S., Chen, L., \& Yang, S. (2019). Adoption Intention of Fintech Services for Bank Users: An Empirical Examination with an Extended Technology Acceptance Model. Symmetry, 11(3), 340. https://doi.org/10.3390/ sym 11030340

Irwin, A. S. M., \& Turner, A. B. (2018). Illicit Bitcoin transactions: challenges in getting to the who, what, when and where. Journal of Money Laundering Control, 21(3), 297-313. https://doi. org/10.1108/JMLC-07-2017-0031

Jagtiani, J., \& John, K. (2018). Fintech: The Impact on Consumers and Regulatory Responses. Journal of Economics and Business, 100, 1-6. https://doi.org/10.1016/j. jeconbus.2018.11.002

Jagtiani, J., \& Lemieux, C. (2018). Do fintech lenders penetrate areas that are underserved by traditional banks? Journal of Economics and Business, 100, 43-54. https://doi.org/10.1016/j. jeconbus.2018.03.001

Kang, J. (2018). Mobile payment in Fintech environment: trends, security challenges, and services. Human-centric Computing and Information Sciences, 8(1), 32. https://doi. org/10.1186/s13673-018-0155-4

Kashyap, M., Garfinkel, H., Shipman, J., Davies, S., \& Nicolacakis, D. (2016). Blurred lines: How FinTech is shaping Financial Services. London: PriceWaterhouseCoopers. Retrieved March 22, 2019, from https://www. pwc.de/de/finanzdienstleistungen/assets/pwcfintech-global-report.pdf

Kim, Y., Choi, J., Park, Y., \& Yeon, J. (2016). The adoption of mobile payment services for "FinTech". International Journal of Applied Engineering Research, 11(2), 1058-1061.

KPMG. (2019). The Pulse of Fintech 2018. Biannual global analysis of investment in Fintech. Amstelveen: KPMG. Retrieved June 22, 2019, from https://assets. kpmg/content/dam/kpmg/xx/ pdf/2019/02/the-pulse-of-fintech-2018.pdf

Lee, I., \& Jae Shin, Y. (2018). Fintech: Ecosystem, business models, investment decisions, and challenges. Business Horizons, 61(1), 35-46. https://doi.org/10.1016/j. bushor.2017.09.003

Magnuson, W. (2018). Regulating Fintech (71 Vanderbilt Law Review 1167). Fort Worth, TX: Texas A\&M University School of Law. Retrieved October 18, 2019, from https:// scholarship.law.tamu.edu/cgi/viewcontent. cgi?article $=2243 \&$ context $=$ facscholar

Omarova, S. T. (2019). New Tech v. New Deal: Fintech as a Systemic Phenomenon. Yale Journal of Regulation, 36(2), 735-793. http://dx.doi.org/10.2139/ssrn.3224393

Ozili, P. K. (2018). Impact of digital finance on financial inclusion and stability. Borsa Istanbul Review, 18(4), 329-340. https://doi. org/10.1016/j.bir.2017.12.003

Raosoft. (2019). Sample Size Calculator by Raosoft. Retrieved November 12, 2019, from http://www.raosoft.com/samplesize.html

Ryu, H.-S. (2018). What makes users willing or hesitant to use Fintech?: the moderating effect of user type. Industrial Management \& Data Systems, 118(3), 541-569. https://doi. org/10.1108/IMDS-07-2017-0325

Schulte, P., \& Liu, G. (2018). FinTech Is Merging with loT and $\mathrm{Al}$ to Challenge Banks: How Entrenched Interests Can Prepare. The Journal of Alternative Investments, 20(3), 41-57. https://doi.org/10.3905/jai.2018.20.3.041

Tavakol, M., \& Dennick, R. (2011). Making Sense of Cronbach's Alpha. International Journal of Medical Education, 2, 53-55. https://doi.org/10.5116/ijme.4dfb.8dfd

Teckla. (2019). Revolut Cryptocurrency Review 2019. Finsof. Retrieved from https:// finsof.net/revolut-cryptocurrency-review-2019

Van Loo, R. (2018). Making Innovation More Competitive: The Case of Fintech (65 UCLA Law Review, pp. 232-279). Boston, MA: Boston University, School of Law. Retrieved from https:// scholarship.law.bu.edu/faculty_scholarship/50/

Williams-Grut, O. (2016). Deloitte just trashed the hype around a $\$ 180$ billion fintech market. Business Insider. Retrieved from https://www.businessinsider.com/deloittereport-marketplace-lending-not-significantplayers-peer-to-peer-2016-5

Wonglimpiyarat, J. (2017). FinTech banking industry: a systemic approach. Foresight, 19(6), 590-603. https://doi.org/10.1108/FS-07-20170026

Zalan, T., \& Toufaily, E. (2017). The Promise of Fintech in Emerging Markets: Not 


\section{Finance}

as Disruptive. Contemporary Economics, 11(4), 415-430. 9254.253

https://doi.org/10.5709/ce.1897-

Zhang, X.-P., \& Kedmey,

D. (2018). A Budding Romance: Finance and Al. IEEE Multimedia, 79-83. Retrieved from https://www. ee.ryerson.ca/ xzhang/publications/mmmag2018-
v25n4-Zhang-Kedmey-A \%20Budding $\% 20$ Romance\%20Finance\%20and\%20AI.pdf

Zigurat. (2019). Evolution of Fintech. Barcelona: Zigurat Innovation \& Technology Business School. Retrieved October 5, 2019, from https://www.e-zigurat.com/innovationschool/blog/evolution-of-fintech/ 